\title{
Nerve Agents - a Clear and Present Danger to Mankind
}

\author{
Miloš P. Stojiljković ${ }^{1}$
}

\begin{abstract}
This editorial is written on the occasion of the 25th anniversary of the infamous sarin and VX terrorist attacks in Japan, in order to increase the awareness of the potential terrorist use of nerve agents and to urge the preparedness to cope with its consequences. Nerve agents are extremely toxic organophosphorus acetylcholinesterase inhibitors, divided in three known groups: G-, V- and A-agents. G-agents tabun, sarin and soman were synthesised in Nazi Germany (1938-1944), V-agents including VX by the British in the 1950s and A-agents or Novichok agents between 1971 and 1993 in the Soviet Union. The use or alleged use of tabun and sarin was mentioned in connection with the Iraq-Iran war (1980-1988) and the Syrian conflict in 2013 and 2017. Sarin and VX were used for terrorist purposes by the Japanese religious sect AUM Shinrikyo in 1994 and 1995. The assassination of Kim Jong Nam with VX took place in Kuala Lumpur, Malesia in 2017, while the 2018 Salisbury and Amesbury poisonings in the UK were ascribed to the so-called Novichok agent A234. Milder cases of poisoning with nerve agents is accompanied by predominantly muscarinic symptomatology and more massive intoxications with mainly nicotinic and central symptoms. Treatment consists of use of atropine, oximes and anticonvulsants.
\end{abstract}

Key words: nerve agent, tabun, sarin, soman, VX, Novichok, atropine, oxime, anticonvulsant.
(1) Department of Pharmacology, Toxicology and Clinical Pharmacology, Faculty of Medicine, University of Banja Luka, Banja Luka, the Republic of Srpska, Bosnia and Herzegovina.

\section{Correspondence:}

MILOŠ P. STOJILJKOVIĆ

E: milos.stojilikovic@med.unibl.org

ARTICLE INFO

Submitted: 23 September 2019 Accepted: 26 September 2019

\section{INTRODUCTION}

The reason why I decided to exercise my editorial prerogatives and write this editorial, was commemoration of quarter of a century after the first terrorist attack with some nerve agent took place - it happened in Matsumoto, Japan, on 27 June 1994 and sarin was then released in the residential part of the city, with 600 people injured and 7 dead. This grim "jubilee" falls also close to the 25th anniversary of the December 1994/January 1995 Osaka and Tokyo VX attacks, with three people poisoned, one of whom died, and heralds quarter of a century after the infamous 20 March 1995 Tokyo subway sarin attack that injured some 5,000 men and women and claimed lives of 12 people. Use or alleged use of sarin, VX and a Novichok agent wrote a new page in the history of terrorism and consti- tute a clear warning that the healthcare systems should be alert and prepared for their use. This is very important, since in many cases precious time was lost because physicians could not recognise the symptomatology of intoxication with an anticholinesterase compound.

\section{BRIEF HISTORY OF NERVE AGENTS}

Ever since they were conceived as a new and the deadliest class of chemical warfare agents in late 1930s in Gerhard Schrader's laboratory of IG Farbenindustrie in Nazi Germany (hence the NATO code G-agents, for German), nerve agents have threatened to be the most nefarious means of mass destruction. After the synthesis 
of tabun in 1936, sarin (1938) and soman (1944) followed, coded by North Atlantic Treaty Organisation (NATO) GA, GB and GD, respectively, but none of them was used during the World War II. The same goes for the second subclass of nerve agents (V-agents; V was for "venomous") synthesised by the British in the 1950s. The best known among them is VX that became part of the US nerve agent armamentarium. Leading military powers stockpiled in the 1950 os and 1960 s a substantial arsenal of various nerve agents. Later they were banned by the Chemical Weapons Convention (CWC) of 1993 that came into effect in 1997.

The first documented use of nerve agents was in the Iraq-Iran war (1980-1988), when tabun and sarin use by the Iraqis was proven, along with blistering agent sulphur mustard1. Use of sarin was reported in the Syrian conflict in 2013 and 2017..$^{2}$ Although every use of nerve agents represents act of violation of CWC and automatically constitutes a criminal act against humanity, what gave a new dimension to the problem was their abuse by the non-governmental entities for the purpose of terrorism. The Japanese religious cult AUM Shinrikyo used sarin on two purposes in Matsumoto in June $1994^{3}$ and in Tokyo subway in March 19954 for massive intoxications and VX in December 1994 and January 1995 for assassination of individuals - ex-AUM members and anti-AUM activists, with one fatality, out of three victims. ${ }^{5}$

Similar pattern - percutaneous poisoning with VX was used at the Kula Lumpur International Airport, Malaysia, to assassinate Kim Jong Nam, a North Korean president's half-brother in February 2017. ${ }^{6}$ A member of a special, most toxic and least publicly known subclass of Russian nerve agents called A-agents or the Novichok ("newcomer" in Russian) agents, was allegedly used in the Salisbury poisonings in the UK on 4 March 2018, when the Russian double agent Sergey Skripal and his daughter Yulia Skripal were poisoned, along with a police officer who investigated the case. Novichok agent A234 was found at the Skripal residence in a perfume bottle. ${ }^{7,8}$ All three of them recovered after a lengthy hospitalisation. On 30 June 2018, two people were poisoned with identical clinical presentation after spraying themselves from a container found discarded in a park in Amesbury, some eight miles from Salisbury; one of them died. ${ }^{9}$
Actually, the pattern of terrorist use of sarin and VX or Novichok agent - for massive inhalation poisonings and individual percutaneous assassinations, respectively reflects differences in their physico-chemical properties. Although all nerve agents are frequently called "nerve gases" they are not gases at all. At room temperature, they are either easily evaporating liquids (G-agents) or thick, oily liquids that almost do not evaporate at room temperature at all (V-agents). In fact, sarin has around 2,100-fold higher volatility than VX. ${ }^{10}$

\section{MECHANISM OF TOXICITY OF NERVE AGENTS, SIGNS AND SYMPTOMS}

All these subclasses of nerve agents share the same mechanism - irreversible inhibition of acetylcholinesterase (AChE), with consequential accumulation of high concentrations of acetylcholine and hyperstimulation of postsynaptic cholinoceptors - muscarinic and nicotinic ones. Milder forms of poisoning are accompanied by miosis, rhinorrhoea, tightness in chest and hypersalivation, while more massive intoxications result in mixture of muscarinic, nicotinic and central symptoms, including tonic-clonic convulsions, failure of the respiratory and vasoactive centre and death.

Classically, symptoms of poisonings with nerve agents are divided into three categories: muscarinic, nicotinic and central. (1) Muscarinic signs and symptoms include miosis and compromised accommodation of the eye (hence dim vision), increased secretion of exocrine glands (hypersalivation, bronchorrhoea), increased smooth muscle tone (bronchoconstriction, stimulated peristaltic bowel movements) and hypotension and bradycardia. (2) Stimulation of nicotinic receptors results in skeletal muscle fasciculation and, due to stimulation of nicotinic receptors in sympathetic ganglia, in mydriasis, hypertension and tachycardia. (3) Central effects encompass headache, vertigo, vomiting, convulsions and cessation of the central respiratory drive. ${ }^{11}$ It is believed that even the central effects of nerve agents are consequence of the stimulation of muscarinic and nicotinic receptors in the brain, followed by the secondary stimulation of glutamatergic and opioidergic structures. ${ }^{12}$ Poisoning with high doses of nerve agents brings 
sometimes the dominance of nicotinic signs and symptoms over the expected muscarinic ones, which masks the clinical presentation, postpones the establishment of the correct diagnosis and hence timely administration of atropine and other antidotes. ${ }^{13}$ Such cases were indeed described in sarin-intoxicated patients in the Tokyo subway attack. ${ }^{4}$

\section{THERAPY OF NERVE AGENT POISONING}

Standard therapy is triple: administration of sufficiently high doses of atropine, AChE reactivators - oximes, such as pralidoxime salts (2PAM or P2S), obidoxime (LüH-6) and asoxime (HI-6) and anticonvulsants, mainly diazepam or midazolam.14 Although atropine itself and especially when overdosed, exerts some adverse effects (tachycardia, xerostomia, impaired cognitive functions), it is essential to repeat the single shots of $2 \mathrm{mg}$ each until the proper atropinisation is reached. It is a doctrinary position that mild atropine overdose is less dangerous than untreated anticholinestarese poisoning. ${ }^{11}$

Use of oximes as unique causal antidotes is absolutely preferable, if there are some oximes at hand, but even if there is none, sufficiently high doses of atropine are essential for survival. Anticonvulsants are used as gamma-aminobutyric acid (GABA)-receptor agonists (eg benzodiazepines diazepam or midazolam and barbiturates, such as thiopental sodium) and it is important that they are administered timely, before the convulsions enter deeper into the so-called glutamatergic phase, where only antagonists of glutamate receptors (eg ketamine, memantine or procyclidine) can be effectively utilised. ${ }^{15}$

\section{ACKNOWLEDGEMENTS}

None.

\section{CONFLICT OF INTEREST}

None.

\section{REFERENCES}

1. Marshall E. Iraq's chemical warfare: Case proved. A U.N. team found mustard and nerve gas bombs on the battlefield; now the challenge is to prevent the war from spreading. Science 1984 Apr 13:224(4645):130-2.

2. John H, van der Schans MJ, Koller M, Spruit HET, Worek F, Thiermann H, Noort D. Fatal sarin poisoning in Syria 2013: forensic verification within an international laboratory network. Forensic Toxicol. 2018;36(1):61-71.

3. Morita H, Yanagisawa N, Nakajima T, Shimizu M, Hirabayashi $\mathrm{H}$, Okudera $\mathrm{H}$, et al. Sarin poisoning in Matsumoto, Japan. Lancet 1995 Jul 29;346(8970):290-3.

4. Okumura T, Takasu N, Ishimatsu S, Miyanoki S, Mitsuhashi A, Kumada K, et al. Report on 640 victims of the Tokyo subway sarin attack. Ann Emerg Med 1996 Aug;28(2):129-35.

5. Nozaki H, Aikawa N, Fujishima S, Suzuki M, Shinozawa $\mathrm{Y}$, Hori S, et al. A case of VX poisoning and the difference from sarin. Lancet 1995 Sep 9:346(8976): 698-9.

6. Chemist: Kim Had 1.4 Times Lethal Dosage of VX on Face. Associted Press 2017 Oct 10 [cited 2017-Oct-12]. Available from: https://www.voanews.com/a/northkorea-kim-vx-on-face/4063762.html.

7. Franca TCC, Kitagawa DAS, Cavalcante SFA, da Silva JAV, Nepovimova E, Kuca K. Novichoks: the dangerous fourth generation of chemical weapons. Int $\mathrm{J}$ Mol Sci 2019 Mar 11;20(5). pii: E1222. doi: 10.3390/ ijms20051222.

8. Bhakhoa H, Rhyman L, Ramasami P. Theoretical study of the molecular aspect of the suspected novichok agent A234 of the Skripal poisoning. R Soc Open Sci 2019 Feb 6;6(2):181831. doi: $10.1098 /$ rsos.181831. eCollection 2019 Feb.

9. Amesbury novichok victim's brother says nerve agent was 'found in perfume bottle'. Sky News 2018 Jul 17 [cited 2019-Sep-20]. Available from: https://news.sky. com/story/amesbury-novichok-victims-brother-saysnerve-agent-was-found-in-perfume-bottle-11438688.

10. Sidell F, Takafuji E, Franz D. Medical aspects of chemical and biological warfare. Washington, DC: Office of the Surgeon General United States Army at TMM Publications; 1997. p. 141.

11. Aas P. Further considerations for the medical management of nerve-agent intoxication. Prehosp Disaster Med 2003 Jul-Sep;18(3):208-16.

12. Škrbić R, Stojiljković MP, Ćetković SS, Dobrić S, Jeremić D, Vulović M. Naloxone Antagonizes Soman-induced Central Respiratory Depression in Rats. Basic Clin Pharmacol Toxicol 2017 Jun;120(6):615-20.

13. Balali-Mood M, Saber H. Recent advances in the treatment of organophosphorous poisonings. Iran J Med Sci 2012 Jun;37(2):74-91.

14. Antonijevic B, Stojiljkovic MP. Unequal efficacy of pyridinium oximes in acute organophosphate poisoning. Clin Med Res 2007 Mar;5(1):71-82.

15. Stojiljković MP, Škrbić R, Jokanović M, Bokonjić D, Kilibarda V, Vulović M. Prophylactic potential of memantine against soman poisoning in rats. Toxicology 2019 Mar 15;416:62-74. 